\title{
PEMANFATAAN KONSORSIUM BAKTERI PEREDUKSI SULFAT DAN ZEOLIT ALAM DALAM PENGENDAPAN LOGAM Mn
}

\section{(REDUCING SULPHATE AND NATURAL ZEOLITE IN Mn METAL SEDIMENTATION USING BACTERIA CONSORTIUM)}

\author{
Nur'Aini Purnamaningsih ${ }^{1}$, Endah Retnaningrum ${ }^{2}$, dan Wahyu Wilopo ${ }^{3}$ \\ ${ }^{1}$ Fakultas Matematika dan Ilmu Pengetahuan Alam Universitas Negeri Yogyakarta \\ J1. Colombo No. 1 Yogyakarta 55281 \\ ${ }^{2}$ Fakultas Biologi Universitas Gadjah Mada Yogyakarta \\ Jl. Teknika Selatan Sekip Utara Yogyakarta 55281 \\ ${ }^{3}$ Fakultas Teknik Universitas Gadjah Mada Yogyakarta \\ Jl. Grafika No. 2 Bulaksumur Yogyakarta 55281 \\ e-mail: nur8\#39@yahoo.com
}

\begin{abstract}
Abstrak
Tujuan dari penelitian ini adalah untuk mengetahui pengaruh penambahan zeolit alam Wonosari terhadap aktivitas Bakteri Pereduksi Sulfat dalam pengendapan logam Mn skala continous culture dan mengidentifikasi karakter biofilm Bakteri Pereduksi Sulfat oleh aktivitas konsorsium Bakteri Pereduksi Sulfat pada zeolit alam dalam skala continous culture. Tahap penelitian meliputi aktivasi zeolit, pengujian aktivitas konsorsium Bakteri Pereduksi Sulfat dalam skala continous culture; serta karakterisasi biofilm konsorsium Bakteri Pereduksi Sulfat. Konsorsium Bakteri Pereduksi Sulfat yang digunakan berasal dari kotoran kambing. Zeolit yang digunakan pada pengujian aktivitas konsorsium Bakteri Pereduksi Sulfat adalah zeolit alam Wonosari. Hasil penelitian menunjukkan bahwa konsorsium Bakteri Pereduksi Sulfat pada bioreaktor dengan penambahan zeolit mempunyai aktivitas yang lebih efektif dibandingkan dengan bioreaktor tanpa penambahan zeolit, dimana pH meningkat menjadi pH 6,9; efisiensi pengendapan logam Mn sebesar 61,16\%, serta nilai MPN yang lebih tinggi dari kontrol. Zeolit dalam bioreaktor dengan waktu pembentukan biofilm 5 hari dan 9 hari terlihat adanya biofilm konsorsium Bakteri Pereduksi Sulfat yang tumbuh melekat pada permukaan zeolit.
\end{abstract}

Kata kunci: zeolit, Bakteri Pereduksi Sulfat, continous culture, biofilm

\begin{abstract}
This study was aimed at determining the effects of natural zeolite from Wonosari on the activites of Sulphate Reducing Bacteria in Mangan (Mn) deposition of continous culture scale, and identifying the biofilm character of Sulphate Reducing Bacteria on consortium activites on natural zeolite using continous culture scale. The first step was activation of zeolites, followed by testing the activity of consortium activities of Sulphate Reduction Bacteria in continuous culture scales; and biofilm characterization of Sulphate Reducing Bacteria consortium. The consortium of Sulphate Reducing Bacteria derived from goat feces. The size of zeo natural zeolites that used in the consortium activity test of Sulphate Reducing Bacteria in Mangan sedimentation was from Wonosari. The results show that the consortium of Sulphate
\end{abstract}


Reducing Bacteria in the bioreactor with the addition of zeolite had an activity that was more effective than the bioreactor without the addition of zeolite, where the pH is increased to $\mathrm{pH}$ 6.9; Mangan sedimentation is $61.16 \%$, and the higher MPN index than the control. Zeolite in a bioreactor with biofilm formation in $5^{\text {th }}$ days and $9^{\text {th }}$ days seems that there are biofilm consortium of Sulphate Reducing Bacteria growing attached to the surface of the zeolite.

Keywords: zeolite, sulfate reducing bacteria, continous culture, biofilm

\section{PENDAHULUAN}

Aktivitas industri di beberapa daerah di Indonesia semakin meningkat, sehingga menyebabkan pencemaran lingkungan akibat berbagai jenis limbah yang dihasilkan dari kegiatan industri. Limbah industri tambang mineral umumnya menyebabkan air mempunyai kandungan sulfat yang tinggi dan $\mathrm{pH}<3$. Salah satu dampak penurunan $\mathrm{pH}$ tersebut adalah meningkatnya kelarutan logam, termasuk logam Mn, sehingga dapat menimbulkan pencemaran logam pada lingkungan perairan.

Salah satu alternatif proses penanganan pencemaran secara biologis dengan memanfaatkan aktivitas mikrobia yaitu dengan menggunakan Bakteri Pereduksi Sulfat. Bakteri ini mampu mendekontaminasi sulfat dan mampu menurunkan konsentrasi logam. Bakteri Pereduksi Sulfat pada umumnya bersifat anaerob dan dapat bereaksi dengan berbagai logam menghasilkan hidrogen sulfida $\left(\mathrm{H}_{2} \mathrm{~S}\right)$ (Widyati, 2006).

Suyasa (2002) menyatakan bahwa terbentuknya hidrogen sulfida juga sangat menguntungkan terhadap lingkungan yang mengandung logam terlarut tinggi. Karena senyawa ini sangat reaktif dan bereaksi dengan logam membentuk logam sulfida yang sangat stabil. Pemanfaatan Bakteri Pereduksi Sulfat sebagai agensia pendetoksifikasi merupakan pendekatan untuk proses bioremidiasi lingkungan. Bakteri tersebut mampu tumbuh pada lingkungan asam dan kandungan logam Mn yang lebih efektif dengan membentuk biofilm. Biofilm merupakan bentuk koloni yang terdiri dari berbagai kelompok bakteri yang melekat pada permukaan suatu substrat (Rajbir, Debrati, \& Rakesh, 2006).

Proses reduksi sulfat dan pengikatan logam Mn oleh Bakteri Pereduksi Sulfat dapat dikondisikan dalam suatu bioreaktor anaerob. Dalam reaktor tersebut substrat organik yang kompleks tersedia dengan adanya aktivitas fermentasi oleh kelompok bakteri anaerob lainnya. Bakteri Pereduksi Sulfat memerlukan asam organik pendek tertentu untuk respirasi anaerobnya. Aktivitas Bakteri Pereduksi Sulfat dalam bioreaktor diharapkan dapat lebih efektif dengan pemberian zeolit alam dari Wonosari. 
Hasil penelitian Pujiastuti dan Saputro (2007) mengenai penurunan kadar Zn dalam limbah elektroplating pada berbagai ukuran zeolit didapatkan bahwa $\mathrm{Zn}$ dalam limbah elektroplating dengan konsentrasi awal 1,6 ppm dapat diserap oleh zeolit sampai 99,25\%; dimana kenaikan penyerapannya semakin tinggi dengan semakin kecil ukuran zeolit yang digunakan, karena semakin kecil ukuran zeolit luas permukaan penyerapannya semakin besar. Penelitian sebelumnya Widyati (2007) menunjukkan bahwa Bakteri Pereduksi Sulfat (BPS) yang diisolasi dari sludge industri kertas dengan dosis $1 \%$ (berat/ volume) dalam waktu 1 hari dapat mereduksi sulfat, dosis inokulum $10 \%$ (berat/ volume) dapat menurunkan konsentrasi sulfat dan Mn dalam waktu 2-4 hari. Fahruddin (2009) melaporkan penggunaan sedimen wetland rawa sebagai sumber Bakteri Pereduksi Sulfat dalam pengolahan limbah asam tambang menunjukkan bahwa Bakteri Pereduksi Sulfat dapat meningkatkan pH sampai 7,3.

Penelitian yang melaporkan tentang penambahan zeolit alam untuk aktivitas konsorsium Bakteri Pereduksi Sulfat belum pernah dilakukan. Oleh karena itu, dalam penelitian ini akan dilakukan penelitian untuk mengetahui pengaruh penambahan zeolit alam Wonosari terhadap aktivitas BakteriPereduksi Sulfatdalampengendapan logam Mn skala continous culture dan mengidentifikasi karakter biofilm Bakteri Pereduksi Sulfat oleh aktivitas konsorsium Bakteri Pereduksi Sulfat pada zeolit alam dalam skala continous culture.

\section{METODE PENELITIAN}

Penelitian ini dilakukan dalam beberapa tahap, antara lain aktivasi zeolit, pengujian aktivitas konsorsium Bakteri Pereduksi Sulfat dalam skala continous culture (dalam bioreaktor); serta karakterisasi biofilm konsorsium Bakteri Pereduksi Sulfat. Parameter yang diamati selama penelitian antara lain $\mathrm{pH}$, konsentrasi sulfat, konsentrasi Mn, dan biofilm pada zeolit.

Mikrobia yang digunakan yakni Konsorsium Bakteri Pereduksi Sulfat yang berasal dari kotoran kambing yang diambil dari peternakan kambing di Kotagede Yogyakarta. Zeolit yang digunakan yaitu zeolit alam Wonosari.

Media untuk pertumbuhan Konsorsium Bakteri Pereduksi Sulfat (BPS) dilakukan dengan media Postgate (Atlas \& Park, 1993), dimana komposisi untuk satu liter media cair terdiri dari magnesium sulfat (1,0 g), ammonium klorida (0,5 g), kalium dihidrogen fosfat (1,0 g), glukosa $(0,1 \mathrm{~g})$, kalsium klorida $(0,1 \mathrm{~g})$, natrium sulfat $(0,5$ $\mathrm{g})$, ekstrak khamir $(0,1 \mathrm{~g})$, natrium laktat ( 8 $\mathrm{ml})$, iron sulfat $(0,1 \mathrm{~g})$, asam askorbat $(0,5$ g). Limbah sintetik yang digunakan untuk 
pengujian aktivitas Konsorsium BPS yakni medium Postgate cair yang ditambahkan sulfat sebanyak 100 ppm dan Mn sebanyak $10 \mathrm{ppm}$. Mn yang digunakan yaitu mangan (II) sulfat $\left(\mathrm{MnSO}_{4} \cdot \mathrm{H}_{2} \mathrm{O}, \mathrm{Mr}=168,91 \mathrm{~g}\right.$ mol-1).

Alat yang akan digunakan antara lain alat gelas (Pyrex), timbangan analitik (Acis), bunsen, penyaring, $\mathrm{pH}$ indikator (Merck), pH meter (Metrohm), oven, Laminar Air Flow, inkubator, vortex, autoclave, dua set bioreaktor, stopwatch, Spektrofotometer UV-Vis (Shimadzu UV1601), Atomic Absorbtion Spektrofotometer (Hitachi Z-2000), dan SEM-EDX (JEOL JSM-6510LA).

Zeolit alam Wonosari direndam dengan akuades selama 24 jam pada temperatur kamar. Perendaman ini bertujuan untuk menghilangkan pengotor-pengotor larut air yang terdapat dalam kerangka zeolit. Zeolit yang sudah direndam tersebut kemudian disaring dengan menggunakan penyaring dan dikeringkan dalam oven selama 24 jam pada temperatur $80^{\circ} \mathrm{C}$ untuk menguapkan air yang terdapat dalam permukaan zeolit sehingga membuka pori-pori dari zeolit.

Ada dua set bioreaktor yang digunakan dalam penelitian ini. Satu set bioreaktor merupakan pengolahan dengan penambahan zeolit dan satu set bioreaktor tanpa penambahan zeolit. Unit pengolahan limbah sintetik menggunakan konsorsium
Bakteri Pereduksi Sulfat terdiri dari tiga bak, yakni bak pengisi, bak pengolah dan bak penampung. Volume bak pengisi sebesar $6.000 \mathrm{ml}$, dan pada bak pengolah terdapat perlakuan dengan dan tanpa penambahan zeolit alam Wonosari.

Limbah sintetik berupa media Postgate yang ditambahkan sulfat sebesar 100 ppm dan Mn sebesar 10 ppm pada bak pengisi dialirkan ke dalam bak pengolah. Pada perlakuan dengan penambahan zeolit alam, bak pengolah diisi dengan sumber inokulum konsorsium Bakteri Pereduksi Sulfat dan zeolit alam Wonosari yang telah dipreparasi dan disterilisasi menggunakan autoclave. Sedangkan bak pengolah tanpa penambahan zeolit hanya berisi konsorsium Bakteri Pereduksi Sulfat. Rancangan bioreaktor pengolahan limbah sintetik ditunjukkan pada Gambar 1.

Pengamatan pada bioreaktor dilakukan selama sembilan hari, dimana sampel yang keluar pada bak penampung dianalisis $\mathrm{pH}$, sulfat dan Mn pada hari ke-0, 3, 5, 7 dan 9. Sedangkan untuk mengetahui pembentukan biofilm pada zeolit digunakan metode Most Probable Number (MPN) untuk menduga jumlah populasi bakteri, dianalisis pada hari ke-5 dan 9. Pada analisis MPN, tabung kultur diinkubasi pada suhu kamar (30 $\pm 2^{\circ} \mathrm{C}$ ) selama 14 hari. Setelah 14 hari, dilakukan pengamatan dengan melihat jumlah tabung kultur yang menghitam 
Pemanfataan Konsorsium Bakteri Pereduksi (Purnamaningsih, N.A., dkk.)

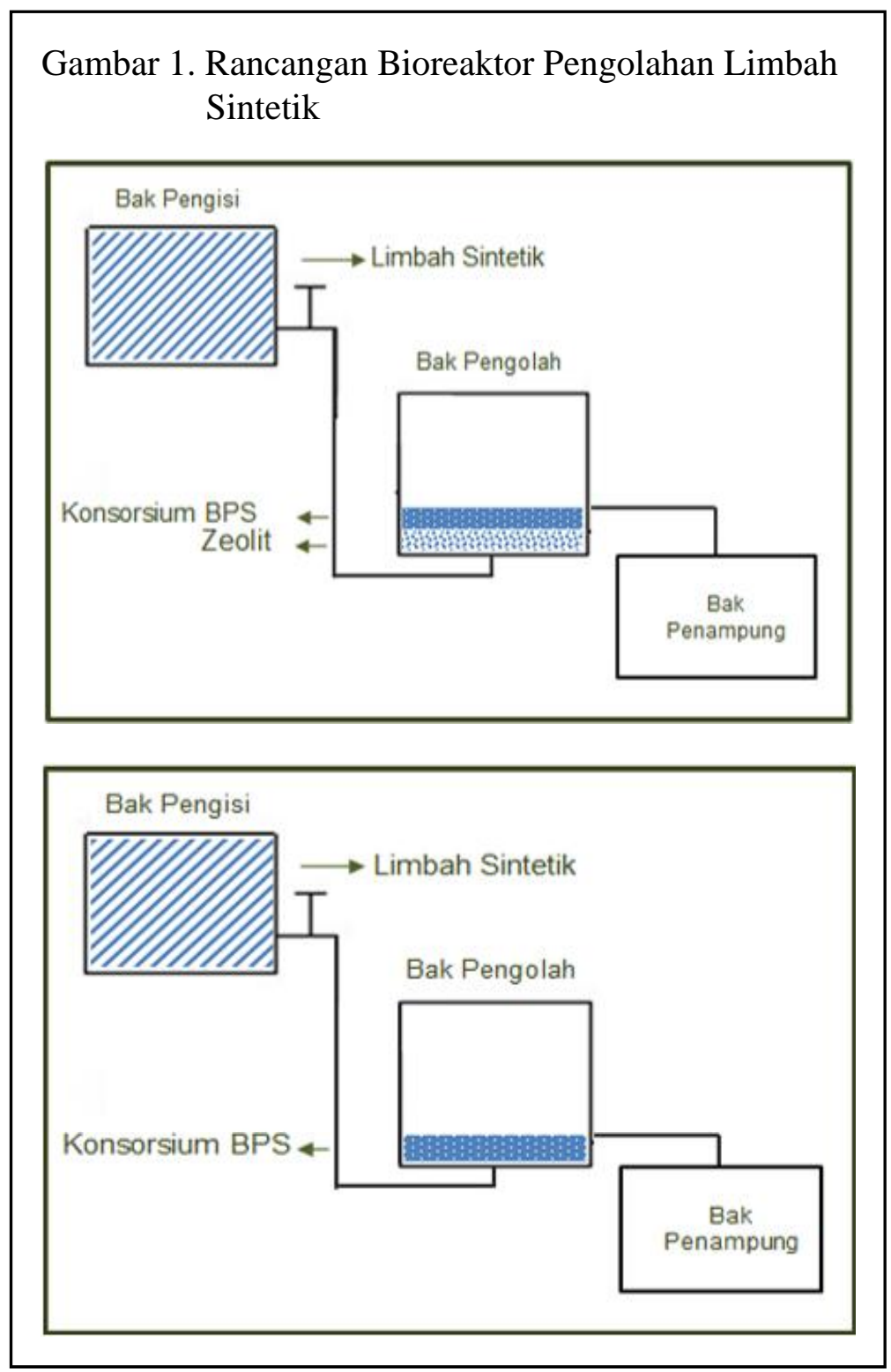

yang menunjukkan terbentuknya endapan sulfide yang mengindikasikan tumbuhnya konsorsium Bakteri Pereduksi Sulfat. Pembacaan hasil dari uji MPN dengan menghitung jumlah tabung yang positif. Angka yang diperoleh dicocokkan dengan tabel MPN.

Pengamatan karakter molekuler pembentukan biofilm konsorsium Bakteri
Pereduksi Sulfat yang menempel pada permukaan zeolit dilakukan dengan Scanning Electron Microscopy-Energy Dispersive X-Ray (SEM-EDX). Analisis SEM-EDX ini dilakukan di Laboratorium Penelitian dan Pengujian Terpadu (LPPT) UGM Yogyakarta. Analisis SEM-EDX ini dilakukan pada permukaan zeolit yang telah terbentuk biofilm konsorsium Bakteri 
Pereduksi Sulfat terpilih dalam pengujian skala continous culture. Hasil dari EDX yaitu tampilan prosentase berupa mass \% dan atom \% dari unsur yang terkandung di dalam bahan. Unsur yang ditampilkan pada grafik bisa dipilih sesuai yang dikehendaki. Untuk penelitian ini adalah unsur Mn.

\section{HASIL DAN PEMBAHASAN}

\section{Pengujian Aktivitas Konsorsium Bakteri} Pereduksi Sulfat dalam Skala Continous

\section{Culture (Bioreaktor)}

Pada penelitian ini konsorsium Bakteri Pereduksi Sulfat yang digunakan berupa kotoran kambing dan zeolit yang ditambahkan adalah zeolit yang berukuran kecil diaplikasikan ke dalam bioreaktor dengan sistem continous culture.

Salah satu keunggulan sistem pengolahan secara bioteknologi dengan memanfaatkan peranan bakteri yaitu pengurangan tingkat keracunan elemen polusi terhadap lingkungan dengan mengandalkan peranan bakteri untuk menyerap, mendegradasi, mentransformasi dan mengimobilisasi zat pencemar (Wahyuni dkk., 2008). Reduksi yang terjadi adalah proses terendapkannya pencemar dalam bentuk tereduksi oleh aktivitas mikroorganisme dalam suatu bioreaktor.

Pengamatan pada bioreaktor dilakukan selama 9 hari, dimana $\mathrm{pH}$, kandungan sulfat, serta logam Mn yang terkandung dalam limbah sintetik diukur pada hari ke 0, 3, 5, 7 dan 9. Hasil analisis $\mathrm{pH}$, konsentrasi sulfat, dan logam Mn ditunjukkan pada Gambar 2.

Gambar 2a menunjukkan bahwa Bioreaktor dengan penambahan zeolit (BZ) mengalami kenaikan $\mathrm{pH}$, dimana $\mathrm{pH}$ awal medium asam ( $\mathrm{pH} 5$ ) menjadi netral $(\mathrm{pH}$ 6,6). Bioreaktor tanpa penambahan zeolit (BTZ) juga mengalami kenaikan $\mathrm{pH}$ menjadi netral $(\mathrm{pH} \mathrm{7,0)}$. Proses reduksi sulfat menjadi sulfida dihasilkan bikarbonat $\left(\mathrm{HCO}_{3}\right)$ menyumbang alkalinitas pada perairan sehingga meningkatkan $\mathrm{pH}$ perairan (Warkentin \& Rowley, 1994).

Bioreaktor dengan penambahan zeolit (BZ) pada Gambar 2b lebih efektif dalam reduksi sulfat dibandingkan bioreaktor tanpa penambahan zeolit (BTZ), dimana hasil pengukuran konsentrasi sulfat pada bioreaktor dengan penambahan zeolit hari ke-7 didapatkan konsentrasi akhir sulfat sebesar 1.037 ppm, sedangkan konsentrasi akhir sulfat bioreaktor tanpa penambahan zeolit sebesar 1.303 ppm.

Bakteri Pereduksi Sulfat adalah kelompok heterotrofik yang menggunakan senyawa organik sederhana sebagai sumber karbon dan mampu hidup pada kondisi lingkungan yang ekstrim. Bakteri Pereduksi Sulfat memanfaatkan sulfat, tiosulfat, sulfit dan senyawa-senyawa sulfur yang dapat direduksi lainnya sebagai akseptor elektron dalam proses respirasi metaboliknya (Madigan et al., 1992). 
Gambar 2. Hubungan Aktivitas Konsorsium Bakteri Pereduksi Sulfat dengan (a) $\mathrm{pH}$ (b) konsentrasi sulfat (c) konsentrasi logam Mn

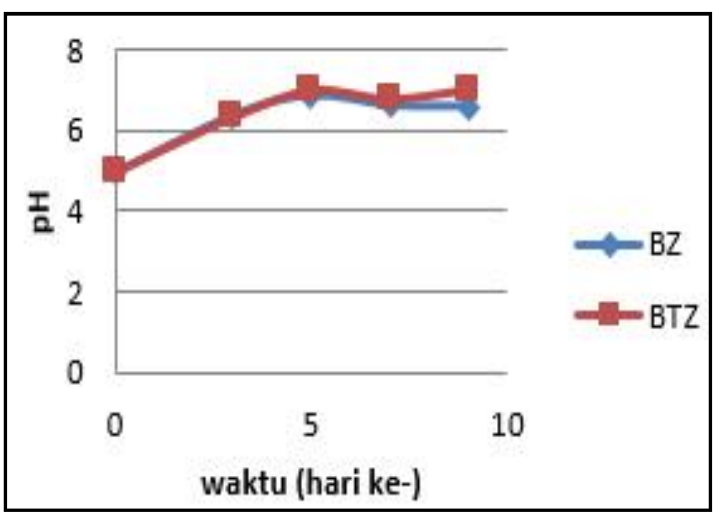

(a)

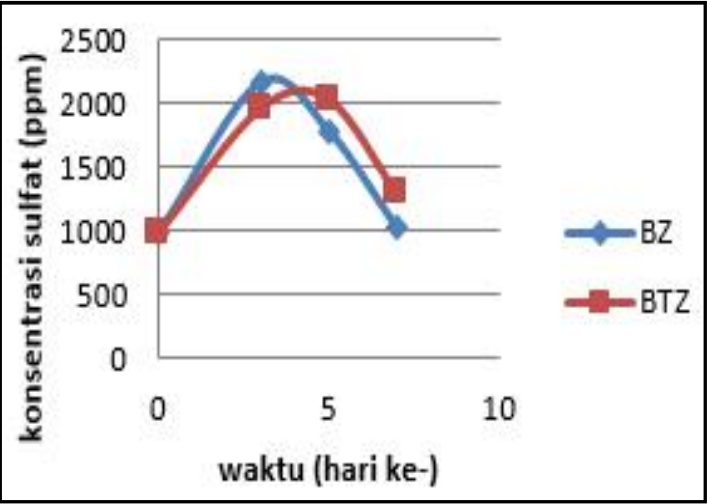

(b)

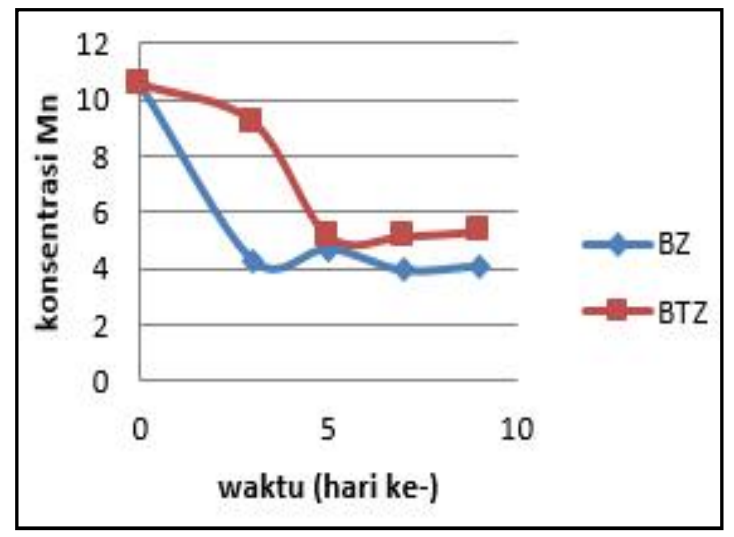

(c)

Dari Gambar 2c. menunjukkan bahwa hasil pengukuran konsentrasi $\mathrm{Mn}$ bioreaktor dengan penambahan zeolit (BZ) lebih efektif, dimana konsentrasi Mn awal dalam limbah sintetik sebesar 10,5270 ppm mengalami reduksi $61,16 \%$ menjadi 4,0885 ppm. Bioreaktor tanpa penambahan zeolit (BTZ) mengalami reduksi Mn sebesar 49,19\% menjadi 5,3485 ppm.

Hasil penelitian Wahyuni (2008) menunjukkan bahwa D. orientis ICBB 1220 toleran terhadap konsentrasi sulfat dan logam terlarut yang tinggi. Penggunaan rangkaian bioreaktor dengan media kompos dan batu vulkanik dapat memperbaiki kualitas air asam tambang ditinjau dari parameter $\mathrm{pH}$, sulfat, dan logam terlarut, dimana $\mathrm{pH}$ meningkat dari 2,85 menjadi 6,98; mereduksi sulfat dari 721,75 menjadi 226,679 (68,59\%); serta mereduksi logam Fe dan Mn masing-masing dari 10,82 menjadi $0,17(98,43 \%)$ dan dari 13,79 menjadi 3,65 (73,52\%). Sulfida yang 
dihasilkan dalam proses reduksi sulfat bereaksi dengan ion-ion logam terlarut membentuk sulfida logam yang tidak larut sehingga konsentrasi logam terlarut dalam air asam tambang menurun (Warkentin \& Rowley, 1994).

Sulfida merupakan bentuk tereduksi dari sulfur (S), sedangkan sulfur dioksida $\left(\mathrm{SO}_{2}\right)$ dan ion sulfat $\left(\mathrm{SO}_{4}^{2-}\right)$ adalah bentuk teroksidasinya. Pembentukan sulfida yang didukung oleh proses biologi konsorsium Bakteri Pereduksi Sulfat dapat mengendapkan ion-ion logam yang toksik seperti $\mathrm{Fe}, \mathrm{Cu}, \mathrm{Mn}, \mathrm{Zn}, \mathrm{Ni}$, dan $\mathrm{Pb}$. Penanganan limbah yang terkontaminasi logam Fe, Zn, Mn, dan Cd secara biologis dengan memanfaatkan Bakteri Pereduksi Sulfat dalam suatu bioreaktor mampu menurunkan kadar logam terlarut tersebut hingga $95 \%$.

Perhitungan jumlah konsorsium Bakteri Pereduksi Sulfat pembentukan biofilm 5 dan 9 hari dengan menggunakan metode Most Probable Number (MPN) dilakukan untuk menduga jumlah populasi bakteri dari masing-masing waktu pembentukan biofilm. Hasil uji MPN pada hari ke-5 dan hari ke-9 dapat dilihat pada Tabel 1 dan Tabel 2.

Hasil analisis Most Probable Number (MPN) menunjukkan bahwa nilai MPN konsorsium Bakteri Pereduksi Sulfat pada bioreaktor dengan penambahan zeolit (BZ) biofilm 5 hari sebesar 2.000 sel per $100 \mathrm{ml}$ dan biofilm 9 hari sebesar 9.300 sel per $100 \mathrm{ml}$. Sedangkan nilai MPN konsorsium Bakteri Pereduksi Sulfat pada bioreaktor tanpa penambahan zeolit (BTZ) biofilm 5 hari yakni <300 sel per100 ml, dan biofilm 9 hari sebesar 900 sel per $100 \mathrm{ml}$. Nilai MPN yang didapat dari bioreaktor dengan penambahan zeolit (BZ) lebih tinggi dibandingkan dengan nilai MPN yang didapat dari bioreaktor tanpa

Tabel 1

MPN Konsorsium Bakteri Pereduksi Sulfat pada Hari ke-5

\begin{tabular}{clcccc}
\hline \multirow{2}{*}{ No } & \multicolumn{1}{c}{ Sampel } & \multicolumn{3}{c}{$\begin{array}{c}\text { Variasi Pengenceran } \\
\text { dan Hasil Positif }\end{array}$} & \multirow{2}{*}{$\begin{array}{c}\text { MPN Indeks } \\
\text { (sel/ 100 ml) }\end{array}$} \\
\cline { 3 - 4 } & & $3 \times 10^{-1}$ & $3 \times 10^{-2}$ & $3 \times 10^{-3}$ & \\
\hline 1 & KK + Zeolit (BZ) & 2 & 1 & 1 & 2.000 \\
2 & KK (BTZ) & 0 & 0 & 0 & $<300$ \\
\hline Keterangan: & $\begin{array}{l}\text { Bioreaktor konsorsium Bakteri Pereduksi Sulfat berupa kotoran kambing } \\
\text { dengan penambahan zeolit }\end{array}$ \\
BTZ $=\begin{array}{l}\text { Bioreaktor konsorsium Bakteri Pereduksi Sulfat berupa kotoran kambing } \\
\text { tanpa penambahan zeolite }\end{array}$
\end{tabular}


Pemanfataan Konsorsium Bakteri Pereduksi (Purnamaningsih, N.A., dkk.)

Tabel 2

MPN Konsorsium Bakteri Pereduksi Sulfat pada Hari ke-9

\begin{tabular}{|c|c|c|c|c|c|}
\hline \multirow[t]{2}{*}{ No } & \multirow[t]{2}{*}{ Sampel } & \multicolumn{3}{|c|}{$\begin{array}{l}\text { Variasi Pengenceran } \\
\text { dan Hasil Positif }\end{array}$} & \multirow{2}{*}{$\begin{array}{l}\text { MPN Indeks } \\
(\mathrm{sel} / 100 \mathrm{ml})\end{array}$} \\
\hline & & $3 \times 10^{-1}$ & $3 \times 10^{-2}$ & $3 \times 10^{-3}$ & \\
\hline 1 & KK + Zeolit (BZ) & 3 & 2 & 0 & 9.300 \\
\hline 2 & KK (BTZ) & 2 & 0 & 0 & 900 \\
\hline \multicolumn{6}{|c|}{ Keterangan: } \\
\hline \multicolumn{6}{|l|}{$\mathrm{BZ}$} \\
\hline \multicolumn{6}{|c|}{$\begin{aligned} \text { BTZ = } & \text { Bioreaktor konsorsium Bakteri Pereduksi Sulfat berupa kotoran kambing } \\
& \text { tanpa penambahan zeolit }\end{aligned}$} \\
\hline
\end{tabular}

penambahan zeolit. Hal ini dikarenakan konsorsium Bakteri Pereduksi Sulfat pada bioreaktor dengan penambahan zeolit dapat membentuk biofilm untuk melekatkan diri pada permukaan zeolit, sehingga biofilm dan polimer-polimer ekstraseluler dapat tumbuh dan melekat pada media pendukung.

Penggunaan kotoran kambing dan zeolit sangat mendukung kinerja bioreaktor dalam pengolahan limbah sintetik. Sumber konsorsium Bakteri Pereduksi Sulfat berupa kotoran kambing sangat berperan dalam reduksi sulfat dan logam $\mathrm{Mn}$, serta dengan adanya penambahan zeolit sangat mendukung dalam pertumbuhan biofilm konsorsium Bakteri pereduksi Sulfat untuk melekatkan diri dan melindungi dari abrasi air limbah.

Dari hasil analisis $\mathrm{pH}$, sulfat, $\mathrm{Mn}$, dan MPN tersebut menunjukkan bahwa konsorsium Bakteri Pereduksi Sulfat pada bioreaktor dengan penambahan zeolit (BZ) mempunyai aktivitas yang lebih tinggi dibandingkan dengan bioreaktor tanpa penambahan zeolit (BTZ). Bioreaktor dengan penambahan zeolit (BZ) yang digunakan dalam penelitian ini memakai sistem reaktor dengan pertumbuhan melekat. Dalam sistem ini mikrobia tumbuh pada media pendukung berupa zeolit membentuk biofilm untuk melekatkan diri pada permukaan zeolit sehingga biofilm dan polimer-polimer ekstraseluler dapat tumbuh dan melekat pada media pendukung. Sedangkan bioreaktor tanpa penambahan zeolit (BTZ) termasuk sistem reaktor pertumbuhan tersuspensi, sehingga biofilm tumbuh dan berkembang dalam keadaan tersuspensi dalam air sehingga aktivitas mikrobia menjadi kurang optimal.

Zeolit yang digunakan dalam penelitian ini sangat berperan dalam proses pengolahan limbah sintetik yang 
mengandung sulfat dan logam Mn. Dengan mengimobilisasi sel-sel bakteri pada suatu permukaan partikel padatan dan terbentuk biofilm, efektivitas kinerja bakteri dalam mereduksi sulfat dan mengendapkan logam dapat meningkat. Bioreaktor yang digunakan dalam penelitian ini dengan sistem pertumbuhan melekat, dimana mikrobia tumbuh di atas zeolit membentuk lapisan biofilm untuk melekatkan diri pada permukaan zeolit.

Hasil dari EDX dari zeolit yang telah dianalisis, didapatkan presentase unsur yang terkandung di dalam bahan, yakni zeolit tanpa perlakuan (kontrol) memiliki kandungan Mn 0\%, zeolit perlakuan hari ke-5 mengandung Mn 0,15\%, dan zeolit perlakuan hari ke-9 mengandung Mn 0,88\% yang ditunjukkan pada Tabel 3.

Pengamatan karakter molekuler pertumbuhan bakteri pereduksi sulfat yang menempel pada zeolit dilakukan dengan menggunakan Scanning Electron Microscopy-Energy Dispersion X-Ray (SEM-EDX). Berikut ini merupakan

Tabel 3

Presentase Unsur Mn yang Terkandung pada Zeolit

\begin{tabular}{lr}
\hline \multicolumn{1}{c}{ Zeolit } & Mangan (Mn) \\
\hline Kontrol & $0,00 \%$ \\
Perlakuan hari ke-5 & $0,15 \%$ \\
Perlakuan hari ke-9 & $0,88 \%$ \\
\hline
\end{tabular}

hasil pengamatan foto SEM zeolit tanpa perlakuan (kontrol), zeolit perlakuan hari ke-5, dan zeolit perlakuan hari ke-9 (Gambar 3).

Gambar 3a menunjukkan bahwa zeolit tanpa perlakuan (kontrol) tidak terbentuk biofilm, namun hanya terlihat ronggarongga pada permukaan zeolit. Gambar $3 b$ menunjukkan bahwa zeolit dalam waktu pembentukan biofilm 5 hari sudah terlihat adanya biofilm dan polimer-polimer ekstraseluler yang tumbuh melekat pada permukaan zeolit. Biofilm dan polimerpolimer ekstraseluler yang terdapat pada zeolit juga berperan dalam proses reduksi sulfat dan logam Mn. Pada Gambar 3c secara visual dapat dilihat bahwa zeolit dalam waktu pembentukan biofilm 9 hari relatif lebih padat dibandingkan zeolit dalam waktu pembentukan biofilm 5 hari. Hal ini disebabkan karena waktu pembentukan biofilm lebih lama, sehingga pembentukan sel-sel bakteri yang terikat ke matriks dan senyawa ekstraseluler pada biofilm lebih tinggi.

Polimer ekstraseluler pada bio-film mempunyai tiga fungsi yaitu mengimobilisasi air pada biofilm, menjerat logam-logam dan produk-produk proses korosi pada substrat, dan menurunkan laju difusi dari dan menuju substrat. 
Gambar 3. Foto Permukaan Zeolit Hasil Pengamatan dengan Scanning Electron Microscopy Perbesaran 10.000x (a) kontrol, (b) Konsorsium Bakteri Pereduksi Sulfat pada Zeolit pada Hari ke-5, (c) Konsorsium Bakteri Pereduksi Sulfat pada Zeolit pada Hari ke-9

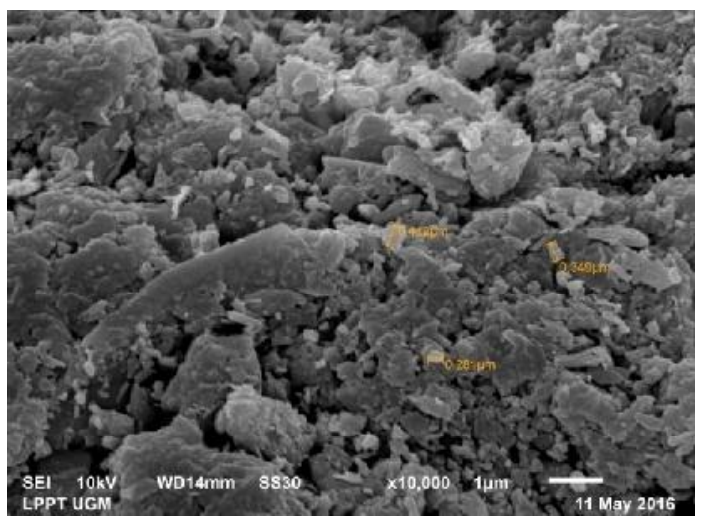

(a)

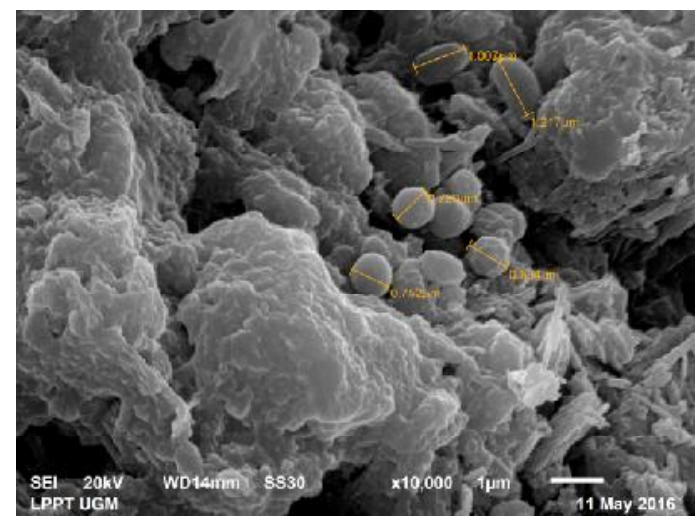

(b)

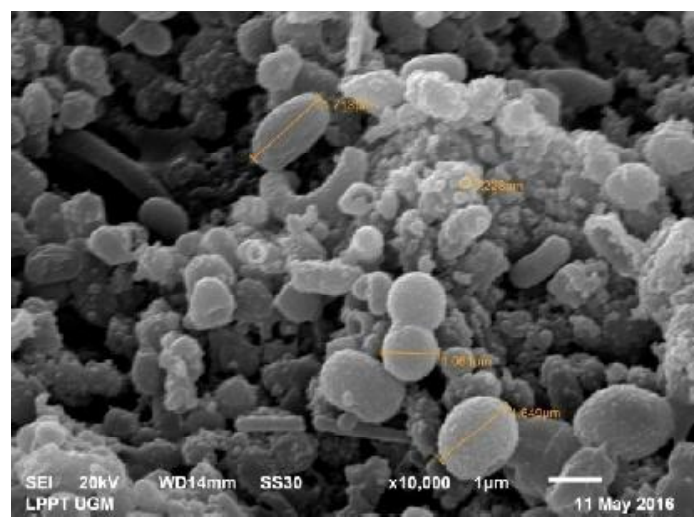

(c)

\section{SIMPULAN}

Konsorsium Bakteri Pereduksi Sulfat pada bioreaktor dengan penambahan zeolit mempunyai aktivitas yang lebih efektif dibandingkan dengan bioreaktor tanpa penambahan zeolit, dimana $\mathrm{pH}$ meningkat menjadi pH 6,9, efisiensi pengendapan logam Mn sebesar 61,16\%, serta nilai MPN yang lebih tinggi. Zeolit dalam bioreaktor dengan waktu pembentukan biofilm 5 hari dan 9 hari terlihat adanya biofilm konsorsium Bakteri Pereduksi Sulfat yang tumbuh melekat pada permukaan zeolit.

\section{DAFTAR PUSTAKA}

Atlas, M. R., \& Parks, L.C. (1993). Handbook of microbiological media. Boca Raton: CRC Press. 
Fahruddin. (2009). Pengaruh jenis desimen wetland dalam reduksi sulfat pada limbah air asam tambang (AAT). J. Tek. Ling, 10(1), 26-30.

Pujiastuti, C., \& Saputro, E. A. (2007, Juli). Pengaruh ukuran zeolit dan penambahan naedta pada penyerapan logam Zn dalam limbah elektroplating. Makalah dipresentasikan pada Seminar Nasional Teknik Kimia Soebardjo Brotohardjono, Surabaya

Rajbir, S., Debrati, P., \& Rakesh, K. J. (2006). Biofilm: Implication in bioremidiation. Institute of Microbial Technology. Article.

Suyasa, I. W. B. (2002). Peningkatan pH dan pengendapan logam berat terlarut air asam tambang (AAT) dengan bakteri pereduksi sulfat dari ekosistem air hitam Kalimantan (Disertasi tidak diterbitkan). Institut Pertanian Bogor, Bogor.
Wahyuni, E. T., Aryanto Y., Setiaji, B., Sastrohamijoyo, H. Wanida, C., \& Webb, J. (2001). Sintesis novel oksida besi di dalam struktur zeolit. Prosiding Seminar Nasional Kimia IX, Yogyakarta.

Warkentin, D. D., \& Rowley, M. V. (1994). Britannia minesite ARD biosulphide demonstration project. Interim ReportLaboratory Testing. NTBC Research Corp, Richmont, BC, Canada.

Widyati, E. (2006). Bioremediasi tanah bekas tambang batubara dengan sludge industri kertas untuk memacu revegetasi lahan (Disertasi tidak diterbitkan). Program Pascasarjana Institut Pertanian, Bogor.

Widyati, E. (2007). Pemanfaatan bakteri pereduksi sulfat untuk bioremediasi tanah bekas tambang batubara. Biodiversitas, 8(4), 283-286. 